\title{
Pain in older adults with dementia
}

\section{Schmerz bei älteren Menschen mit Demenz}

\begin{abstract}
A survey across Europe on current practices, use of assessment tools, guidelines and policies

Eine Umfrage in Europa zu aktueller Praxis, Verwendung von Assessment-Instrumenten, Leitlinien und Handlungsanweisungen
\end{abstract}

S. Zwakhalen, 1,2

R. E. Docking, 2

Ass.-Prof. Dr. rer. medic. I. Gnass, $3{ }^{\infty}$

Phone +43-662-242080379

Email irmela.gnass@pmu.ac.at

E. Sirsch, 4

C. Stewart, 5

N. Allcock, 6

P. Schofield, 2

1 School for Public Health and Primary Care (CAPHRI), Department of Health Services Research, Maastricht University, Maastricht, The Netherlands

2 Faculty of Education and Health, Department of Adult Nursing and Paramedic Sciences, University of Greenwich, London, UK

3 Institute of Nursing Science and Practice, Paracelsus Medical University, Strubergasse 21, 5020 Salzburg, Austria 
4 Faculty of Nursing Science, Philosophisch-Theologische Hochschule Vallendar (Catholic University), Vallendar, Germany

5 NHS Research Scotland, The Golden Jubilee National Hospital, Clydebank, UK

6 Professional and Clinical Development Lead, InHealth Pain Management Solutions Limited, Barnsley, UK

\section{Abstract}

\section{Background}

We aimed to explore the existing use of pain assessment tools and guidelines, and develop understanding of the practical considerations required to facilitate their use within the nursing home, hospital and community settings.

\section{Methods}

A self-administered web-based survey was conducted with nurses, health and social care workers with an interest in the assessment of pain in older adults with cognitive impairment. The survey was distributed to participants in Austria, Belgium, Denmark, Germany, The Netherlands, Switzerland and United Kingdom.

\section{Results}

Only a minority of staff reported use of (inter-)national or local standards or specific pain assessment tools in daily practice. A range of tools were reported as being used, which varied across country. While participants generally reported that these pain assessment tools were easy/very easy to use, many participants reported that they were difficult to interpret. Assessment is generally performed whilst providing nursing care. This was highlighted in $70-80 \%$ of all participating countries. While many of these tools rely on facial expression of pain, facial expressions were considered to 
be the least useful in comparison to other items. Furthermore findings showed that nurses employed in long-term care settings did not feel that they were educated enough in pain assessment and management.

\section{Conclusion}

Our findings suggest that pain education is required across all countries surveyed. This should include a focus on guidelines and standards for assessment and subsequent management of pain. Findings suggest that clinical staff find interpreting facial expressions in relation to pain more difficult.

\section{Zusammenfassung}

\section{Hintergrund}

Wir untersuchten die bestehende Anwendung von Schmerzeinschätzungsinstrumenten und -richtlinien, um ein Verständnis der Überlegungen in der Praxis zu entwickeln, die erforderlich sind, um die Anwendung in Pflegeheimen, Krankenhäusern und Gemeinden zu erleichtern. AQ1

\section{Methoden}

Eine selbstverwaltete, webbasierte Umfrage wurde mit Gesundheits- und Krankenpflegenden sowie Gesundheits- und Sozialarbeitern durchgeführt, die für die Einschätzung von Schmerzen bei älteren Menschen mit kognitiver Beeinträchtigung verantwortlich sind. Die Umfrage wurde an Teilnehmer in Österreich, Belgien, Dänemark, Deutschland, den Niederlanden, der Schweiz und Großbritannien verteilt.

\section{Ergebnisse}

Nur eine Minderheit der Mitarbeitenden berichtete über den Einsatz von (inter-)nationalen oder einrichtungsspezifischen Standards oder von 
spezifischen Schmerzeinschätzungsinstrumenten in der täglichen Pflegepraxis. Die Verwendung einer Reihe von Instrumenten wurde berichtet, diese unterscheiden sich von Land zu Land. Die Teilnehmenden berichteten, dass diese Schmerzeinschätzungsinstrumente generell einfach/sehr einfach zu bedienen, dass aber die Ergebnisse schwer zu interpretieren seien. Die Schmerzeinschätzung erfolgt in der Regel während pflegerischer Handlungen. Dies wurde in $70-80 \%$ aller teilnehmenden Länder hervorgehoben. In den meisten Instrumenten erfolgt eine Einschätzung des Gesichtsausdrucks, doch wurde dieser als am wenigsten nützlich im Vergleich zu anderen Verhaltensmerkmalen/-kategorien angesehen. Darüber hinaus zeigten die Ergebnisse, dass Gesundheits- und Krankenpflegende, die in Pflegeeinrichtungen beschäftigt waren, sich nicht ausreichend in der Schmerzeinschätzung und dem Schmerzmanagement ausgebildet fühlten.

\section{Schlussfolgerung}

Unsere Ergebnisse lassen vermuten, dass in allen untersuchten Ländern Fortund Weiterbildungen zum Schmerz erforderlich sind. Darin enthalten sein sollte ein Schwerpunkt auf Leitlinien und Standards für die Einschätzung und anschließende Behandlung von Schmerzen. Die Ergebnisse deuten darauf hin, dass klinisch tätige Pflegende die Interpretation des Gesichtsausdrucks in Bezug auf Schmerzen schwierig finden.

\section{Keywords}

\section{$\mathrm{AQ}_{2}$}

Pain assessment

Older adults

Proxy assessment

Guidelines

Survey

\section{Schlüsselwörter}

Schmerzeinschätzung

Ältere Menschen

Fremdeinschätzung 
Leitlinien

Umfrage

\section{Introduction}

\section{$\mathrm{AQ}_{3}$}

Many older adults experience a 'double jeopardy', the co-occurrence of pain and dementia [37]. Pain is a prevalent problem amongst older adults, particularly disabling pain or pain sufficient to interfere with day-to-day living $[14,15,32]$. The prevalence of chronic pain in nursing homes ranges from $45-$ $80 \%[2,30]$ and it is estimated that at least $50 \%$ of adults being treated in acute care report pain $[12,24]$. Dementia affects approximately 35.6 million persons globally [34] with an estimated 7.3million adults affected residing in Europe [4]. It is predicted that the prevalence of dementia will double every 20 years [16].

$\mathrm{AQ} 4$

The co-morbidity of both pain and impaired cognition is complex. Pain and cognitive impairment are interrelated; unrelieved pain impacts negatively upon cognitive capacity, and conversely, reduced cognition impacts negatively upon pain severity and interference $[29,33]$. Both conditions require effective management to address the many debilitating consequences associated [35]. Previous studies have identified that pain is undertreated, especially in relation to analgesic use, amongst older adults with co-morbid pain and dementia [13, 26]. Appropriate treatment of pain involves both the assessment and management of pain [8]. With an additional need to consider cognitive impairment, treatment can become even more problematic.

The gold standard of pain assessment is the use of self-report techniques [ 10 , 25]. However, cognitive impairment reduces a person's ability to communicate, making it difficult to use and rely upon self-reported pain measures [10, 19]. One solution to this has been the development of pain behaviour observational tools, to be completed by proxy [19]. Over the last decade there have been a variety of observational behavioural scales developed to assess pain in patients with dementia who are unable to use self-report [27, 35]. However, while there are numerous assessment scales available, pain assessment is not performed routinely $[12,23]$. The low use of pain assessment scales has 
previously been described as a substantial barrier against the accurate treatment of older people with pain and dementia [21,22]. Care professionals acknowledged lack of knowledge has also been identified as a fundamental barrier to optimal pain management $[9,11]$. Further exploration of barriers surrounding the use of pain assessment tools is required to optimise pain management. The current study explores the existing use of pain assessment tools and guidelines, and develops understanding of the practical considerations required to facilitate their use within the nursing home, hospital and community settings across Europe. This information will inform further considerations and future development of tools or guidelines for pain assessment in older adults with cognitive impairment.

This paper will address the following key questions:

- What guidelines are currently being used by healthcare professionals and care assistants in nursing home and acute care settings across Europe to assess pain in older adults with dementia?

- What observational tools are currently being used by healthcare professionals and care assistants in nursing home and acute care settings across Europe to assess pain in older adults with dementia?

- What opportunities and challenges are healthcare professionals and care assistants experiencing using such tools?

- What are the differences in use of guideline, tools, experiences and challenges across different work settings and European countries?

\section{Methods}

The self-administered web-based questionnaire was set up by the members of Working Group 2 (WG2) of the COST (European Cooperation in Science and Technology) Action TD1005 Pain Assessment in Patients with Impaired Cognition, especially Dementia, using Survey Monkey®. The survey was conducted with healthcare professionals and care assistants with an interest in the assessment of pain in older adults with cognitive impairment. The study was distributed to participants in Austria, Belgium, Denmark, Germany, the Netherlands, Switzerland and United Kingdom, and was conducted between 
September and November 2013.

AQ5

\section{Survey}

The authors developed the survey questions in English. Focus of the survey was to explore the current use and opinions of practitioners on the usefulness and usability of existing tools to identify attitudes towards assessment tools and possible barriers to their implementation.

Alongside sociodemographic data, the survey contained questions about participants' knowledge and use of existing pain assessment guidelines, the usage of existing pain assessment tools and the experience healthcare professionals have of using these tools in daily practice. The questionnaire included both open ended and multiple-choice questions.

Native speaking COST members translated the survey into German and Dutch using a forward backward procedure. The questionnaire was piloted with 6 nurses from England ( $n=2)$, Germany $(n=2)$ and the Netherlands $(n=2)$ to ensure the relevance of the questions across the countries involved. Feedback was given on comprehensiveness and usability of the questionnaire. Minor modifications were necessary to clarify aspects on the different levels of qualifications and healthcare settings in the participating countries. The final instrument contained 36 questions.

\section{Data collection}

The survey used an opportunistic sample of healthcare staff. A sample size calculation was not performed since the study aimed to describe the currently used guidelines or observational tools for pain assessment amongst older adults with cognitive impairment. Targeted strategies were adopted in each country to circulate the link for the web-based questionnaire. The survey was distributed amongst all COST Action 1005 Members $(n=64)$, as well as via different professional groups in each country. In Germany the information was sent to all members of the German Association for Nursing Science via newsletter and announcement on the association's own website. Main educational centres for pain management in Germany also distributed the questionnaire. The cooperative associations in Switzerland and Austria also invited people to 
participate and distributed the survey link to all members. In the Netherlands the survey link was distributed via the pain society, and nursing and pain organisation. In the UK the survey link was circulated via email, newsletters and websites through the British Pain Society and relevant Royal College of Nursing (RCN) forums (those relating to pain and palliative care and care of older adults). Respondents were not required to enter their name and therefore the survey was completed anonymously. Respondents had the opportunity to stop completion of the survey at any moment, which could result in an incomplete survey.

\section{Analysis}

Quantitative data was analysed using SPSS and descriptive statistics were performed. For the multiple choice answers valid percentages were used given the variation in number of responses per question. The open-ended questions were analysed using content analysis. The comments to the open-ended questions were analysed by using deductive classification and superordinate categories were created with an open matrix [20]. To verify the responses on the open-ended questions and categories consensual agreement was evaluated by having a peer group reviewing the data. In case of disagreement between the two researchers, it was agreed upon to discuss the differences and seeks for consensus.

\section{Results}

\section{Participants}

The sample $(n=810)$ included 206 healthcare professionals working in hospital care (HC), 127 working in institutional long-term care (ILTC) and 38 in primary care (PC). The majority of respondents $(n=439)$ did not provide information about their work setting. Table 1 shows work-related information of the overall group of participants and per country.

\section{Table 1}

Employment and organisational features in relation to survey participants $(n=810)$ AQ6

\section{DE can't}




\begin{tabular}{|c|c|c|c|c|c|c|c|c|c|}
\hline & \multirow{2}{*}{$\begin{array}{l}\text { Overall } \\
n=810\end{array}$} & \multirow{2}{*}{\begin{tabular}{|c|} 
UK \\
\\
$n=$ \\
28
\end{tabular}} & \multirow{2}{*}{$\begin{array}{l}\text { NL } \\
\\
\\
n= \\
139\end{array}$} & \multirow{2}{*}{$\begin{array}{l}\text { delete the } \\
\text { highlight. } \\
\text { There is no } \\
\text { comment. } \\
\boldsymbol{n}=\mathbf{1 4 7}\end{array}$} & \multirow{2}{*}{$\begin{array}{c}\text { DK } \\
\\
n= \\
9\end{array}$} & \multirow{2}{*}{$\begin{array}{c}\text { BE } \\
\\
\\
n= \\
35\end{array}$} & \multirow{2}{*}{$\begin{array}{c}\text { SUI } \\
\\
n= \\
18\end{array}$} & \multirow{2}{*}{$\begin{array}{c}\text { AT } \\
\boldsymbol{n}= \\
\mathbf{3 9}\end{array}$} \\
\hline & & & & & & & & & \\
\hline \multirow{3}{*}{$\begin{array}{l}\text { Setting } \\
n=\end{array}$} & Hospital & 206 & 16 & 35 & 85 & 2 & 21 & 7 & 35 \\
\hline & $I L T C$ & 127 & 4 & 70 & 26 & 4 & 11 & 7 & 1 \\
\hline & $P C$ & 38 & 6 & 21 & 7 & 1 & 1 & 14 & 1 \\
\hline \multirow{2}{*}{$\begin{array}{l}\text { Organisation } \\
\text { has } \\
\text { dementia } \\
\text { ward }\end{array}$} & Yes & 212 & 8 & 86 & 69 & 3 & 22 & 10 & 9 \\
\hline & No & 195 & 18 & 50 & 71 & 3 & 12 & 7 & 29 \\
\hline \multirow{2}{*}{$\begin{array}{l}\text { Working in } \\
\text { dementia } \\
\text { care ward }\end{array}$} & Yes & 169 & 3 & 74 & 43 & 4 & 17 & 4 & 19 \\
\hline & No & 250 & 24 & 63 & 102 & 5 & 18 & 13 & 19 \\
\hline
\end{tabular}

\section{Use of guidelines}

Of the participants who completed this section $(n=722), 41.8 \%(n=302)$ reported to be not using any national/international standards, guidelines or local policies in their institutions. In addition, a substantial number of respondents $(n=122,17 \%)$ were unsure if their institution had any pain management guidelines.

In all countries diverse guidelines were announced to be in use and surprisingly healthcare professionals additionally named several single pain assessment tools as guidelines or standards for pain assessment in people with dementia.

\section{Use of behavioural pain tools}

Of the respondents who completed this section $(n=590), 58 \%(n=342)$ reported that they did not use any pain assessment tools in current practice. Around onethird $(34.1 \%, n=201)$ reported that they use an observational pain assessment tool for older people with dementia if self-report cannot be obtained. 
Of those who did report use of pain assessment tools, an array of approaches towards pain assessment in older adults with cognitive impairment was presented. Internal standards and documentation systems were also mentioned (Table 2$)$. The PAINAD scale $(n=33,9.3 \%)$, respectively the German translation BESD ([6]; $n=37,10.8 \%$ ), was used in all three languages surveyed. Specific self-report tools reported to be in use included the Faces Pain Scale ([7]; FPS, $n=38$ ), and the Numeric Rating Scale (NRS; $n=35,10.2 \%$ ). Some participants also reported use of non-pain tools such as the Delirium Observation Scale (DOS; [28]; $n=39,11.4 \%$ ).

\section{Table 2}

Tools mentioned for pain assessment in people with dementia

AQ8

\begin{tabular}{|c|c|c|}
\hline $\begin{array}{l}\text { English } \\
\text { language }\end{array}$ & Dutch language & German language \\
\hline $\begin{array}{l}\text { Pain Assessment } \\
\text { in Advanced } \\
\text { Dementia Scale } \\
\text { (PAINAD) }\end{array}$ & $\begin{array}{l}\text { Pain Assessment in } \\
\text { Advanced Dementia Scale } \\
\text { (PAINAD) }\end{array}$ & $\begin{array}{l}\text { Beurteilung von Schmerzen } \\
\text { bei Demenz (BESD) }\end{array}$ \\
\hline Faces Pain Scale & Faces Pain Scale & Faces Pain Scale \\
\hline $\begin{array}{l}\text { Numeric rating } \\
\text { scale }\end{array}$ & Numeric rating scale & Numeric rating scale \\
\hline $\begin{array}{l}\text { Visual analogue } \\
\text { scale }\end{array}$ & Visual analogue scale & Visual analogue scale \\
\hline $\begin{array}{l}\text { Checklist of } \\
\text { Nonverbal Pain } \\
\text { Indicators }\end{array}$ & $\begin{array}{l}\text { Doloplus seale } \\
\text { AQ9 }\end{array}$ & DOLOPLUS \\
\hline \multirow{5}{*}{ Abbey pain scale } & $\begin{array}{l}\text { Pain Assessment Checklist } \\
\text { for Seniors with Limited } \\
\text { Ability to Communicate } \\
\text { (PACSLAC) C }\end{array}$ & $\begin{array}{l}\text { Beobachtungsinstrument für } \\
\text { das Schmerzassessment bei } \\
\text { alten Menschen mit Demenz } \\
\text { (BISAD) }\end{array}$ \\
\hline & $\begin{array}{l}\text { The Rotterdam Elderly Pain } \\
\text { Observation Scale (Repos) }\end{array}$ & ECPA Scale \\
\hline & Scale not specified & $\begin{array}{l}\text { Zurich Observation Pain } \\
\text { Assessment (ZOPA) }\end{array}$ \\
\hline & \multirow[b]{2}{*}{$\begin{array}{l}\text { Delirium Observation } \\
\text { Screening Scale (DOS) }\end{array}$} & Scale not specified \\
\hline & & Behaviour pain scale (BPS) \\
\hline
\end{tabular}


Participants who used pain assessment tools were requested to provide additional information about the usability of these tools (Table 3). The majority of these respondents ( $n=106,52.2 \%)$ mentioned that the tools were (very) easy to use. Furthermore, findings show that most $(n=291,83.9 \%)$ of these respondents complete the observational assessment while providing care for the patient and prefer to do so over a period of time so as to reflect the patient at rest and movement. Participants reported than on average behavioural pain assessments took $3-5 \mathrm{~min}$ to complete with each patient.

\section{Table 3}

Utility of behavioural pain tools

AQ10

\begin{tabular}{|c|c|c|c|c|}
\hline $\begin{array}{l}\text { Behavioural tools in } \\
\text { dementia are ... }\end{array}$ & $\begin{array}{l}\text { Overall } \\
(n=203)\end{array}$ & $\begin{array}{l}\mathrm{HC} \\
(n= \\
86)\end{array}$ & $\begin{array}{l}\text { NH please replace for } \\
\text { ILTC } \ldots(n=66)\end{array}$ & $\begin{array}{l}\mathrm{PC} \\
(n= \\
11)\end{array}$ \\
\hline Very easy to use & $10(4.9)$ & $\begin{array}{l}4 \\
(4.7)\end{array}$ & $2(3.0)$ & $\begin{array}{l}2 \\
(18.2)\end{array}$ \\
\hline Easy to use & $\begin{array}{l}96 \\
(47.3)\end{array}$ & $\begin{array}{l}44 \\
(51.2)\end{array}$ & $35(53.0)$ & $\begin{array}{l}3 \\
(27.3)\end{array}$ \\
\hline Difficult to use & $\begin{array}{l}29 \\
(14.3)\end{array}$ & $\begin{array}{l}11 \\
(12.8)\end{array}$ & $8(12.1)$ & $\begin{array}{l}3 \\
(27.3)\end{array}$ \\
\hline Very difficult to use & $\begin{array}{l}45 \\
(22.2)\end{array}$ & $\begin{array}{l}19 \\
(22.1)\end{array}$ & $12(18.2)$ & $\begin{array}{l}2 \\
(18.2)\end{array}$ \\
\hline Do not use & $23(11.3)$ & $\begin{array}{l}8 \\
(9.3)\end{array}$ & $9(13.6)$ & $\begin{array}{l}1 \\
(9.1)\end{array}$ \\
\hline $\begin{array}{l}\text { Behavioural assessment } \\
\text { would be conducted ... }\end{array}$ & $\begin{array}{l}\text { Overall } \\
(n=347)\end{array}$ & $\begin{array}{l}\mathrm{HC} \\
(n= \\
175)\end{array}$ & $\begin{array}{l}\text { NH } \quad \text { Please replace for } \\
\text { ILTC } \quad(n=82)\end{array}$ & $\begin{array}{l}\mathrm{PC} \\
(n= \\
30)\end{array}$ \\
\hline While caring for a patient & $\begin{array}{l}291 \\
(83.9)\end{array}$ & $\begin{array}{l}152 \\
(86.9)\end{array}$ & $59(72.0)$ & $\begin{array}{l}26 \\
(86.7)\end{array}$ \\
\hline At the end of a shift & $13(3.7)$ & $\begin{array}{l}8 \\
(4.6)\end{array}$ & $4(4.9)$ & - \\
\hline \multirow[t]{2}{*}{ Sometimes after shift } & $\begin{array}{l}43 \\
(12.4)\end{array}$ & $\begin{array}{l}15 \\
(8.6)\end{array}$ & $19(23.2)$ & $\begin{array}{l}4 \\
(13.3)\end{array}$ \\
\hline & & $\mathrm{HC}$ & & $\mathrm{PC}$ \\
\hline
\end{tabular}




\begin{tabular}{|c|c|c|c|c|}
\hline $\begin{array}{l}\text { Behavioural assessment } \\
\text { would be conducted ... }\end{array}$ & $\begin{array}{l}\text { Overall } \\
(n=363)\end{array}$ & $\begin{array}{l}(n= \\
189)\end{array}$ & $\begin{array}{l}\text { NH please replace for } \\
\text { ILTC } \quad(n=82)\end{array}$ & $\begin{array}{l}(n= \\
29)\end{array}$ \\
\hline At rest & $24(6.6)$ & $\begin{array}{l}13 \\
(6.9)\end{array}$ & $7(8.5)$ & $\begin{array}{l}1 \\
(3.4)\end{array}$ \\
\hline $\begin{array}{l}\text { At movement } \\
\text { AQ11 }\end{array}$ & $15(4.1)$ & $\begin{array}{l}6 \\
(3.2)\end{array}$ & $5(6.1)$ & - \\
\hline $\begin{array}{l}\text { Over a period of time } \\
\text { involving rest and movement }\end{array}$ & $\begin{array}{l}324 \\
(89.3)\end{array}$ & $\begin{array}{l}170 \\
(89.9)\end{array}$ & $70(85.4)$ & $\begin{array}{l}28 \\
(96.6)\end{array}$ \\
\hline $\begin{array}{l}\text { Ideally behavioural } \\
\text { assessment would take ... }\end{array}$ & $\begin{array}{l}\text { Overall } \\
(n=428)\end{array}$ & $\begin{array}{l}\mathrm{HC} \\
(n= \\
198)\end{array}$ & $\begin{array}{l}\text { NH please replace for } \\
\text { ILTC } \ldots(n=125)\end{array}$ & $\begin{array}{l}\mathrm{PC} \\
(n= \\
34)\end{array}$ \\
\hline Less than $1 \mathrm{~min}$ & $\begin{array}{l}76 \\
(17.8)\end{array}$ & $\begin{array}{l}48 \\
(24.2)\end{array}$ & $10(8.0)$ & $\begin{array}{l}4 \\
(11.8)\end{array}$ \\
\hline $1-2 \min$ & $\begin{array}{l}62 \\
(14.5)\end{array}$ & $\begin{array}{l}32 \\
(16.2)\end{array}$ & $22(17.6)$ & - \\
\hline $3-5 \mathrm{~min}$ & $\begin{array}{l}162 \\
(37.9)\end{array}$ & $\begin{array}{l}72 \\
(38.9)\end{array}$ & $48(38.4)$ & $\stackrel{9}{(26.5)}$ \\
\hline $6-10 \mathrm{~min}$ & $\begin{array}{l}70 \\
(16.4)\end{array}$ & $\begin{array}{l}22 \\
(11.1)\end{array}$ & $26(20.8)$ & $\begin{array}{l}10 \\
(29.4)\end{array}$ \\
\hline More than $10 \mathrm{~min}$ & $\begin{array}{l}58 \\
(13.6)\end{array}$ & $\begin{array}{l}19 \\
(9.6)\end{array}$ & $19(15.2)$ & $\begin{array}{l}11 \\
(32.0)\end{array}$ \\
\hline $\begin{array}{l}\text { Responding to items would } \\
\text { preferable be done by ... }\end{array}$ & $\begin{array}{l}\text { Overall } \\
(n=)\end{array}$ & $\begin{array}{l}\mathrm{HC} \\
(n= \\
198)\end{array}$ & $\begin{array}{c}\text { NH } \\
\text { ILTC }\end{array}$ & $\begin{array}{l}\mathrm{PC} \\
(n= \\
36)\end{array}$ \\
\hline Easy tick & $\begin{array}{l}131 \\
(30.6)\end{array}$ & $\begin{array}{l}65 \\
(32.8)\end{array}$ & $40(32.5)$ & $\frac{12}{(33.3)}$ \\
\hline Numeric scaling & $\begin{array}{l}156 \\
(36.4)\end{array}$ & $\begin{array}{l}76 \\
(38.4)\end{array}$ & $38(30.9)$ & $\begin{array}{l}13 \\
(36.1)\end{array}$ \\
\hline Selecting categories & $\begin{array}{l}102 \\
(23.8)\end{array}$ & $\begin{array}{l}48 \\
(24.2)\end{array}$ & $33(26.8)$ & $\begin{array}{l}5 \\
(13.9)\end{array}$ \\
\hline Open-ended & $39(9.1)$ & $\begin{array}{l}9 \\
(4.5)\end{array}$ & $12(9.8)$ & $\begin{array}{l}6 \\
(16.7)\end{array}$ \\
\hline
\end{tabular}

$N(\%)$ number of respondents vary per survey question

Regarding the items in the tools, Table 4 shows that healthcare professionals considered verbal, vocal and body movements most important and useful items 
included in pain assessment tools. Although many $(n=253,31.3 \%)$ indicated that facial expressions are useful in assessing pain, these expressions were regarded as being less important in comparison to other expressions of pain (e.g. verbal, vocal or body movements).

\section{Table 4}

Utility of pain items

$\mathrm{AQ12}$

\begin{tabular}{|l|l|l|l|l|l|}
\hline $\begin{array}{c}\text { In } \\
\text { behavioural } \\
\text { pain } \\
\text { assessment } \\
\text { following } \\
\text { items are } \\
\text { considered ... }\end{array}$ & $\begin{array}{c}\text { Facial } \\
\text { expression }\end{array}$ & Verbalisation & Vocalisation & $\begin{array}{c}\text { Body } \\
\text { Movement }\end{array}$ & $\begin{array}{c}\text { Chang } \\
\text { interpe } \\
\text { intera }\end{array}$ \\
\hline Essential & $144(17.8)$ & $195(24.1)$ & $190(23.5)$ & $267(33.0)$ & $134(16$ \\
\hline Very useful & $109(13.5)$ & $203(25.1)$ & $213(26.3)$ & $136(16.8)$ & $202(24$ \\
\hline $\begin{array}{l}\text { Slightly } \\
\text { useful }\end{array}$ & $7(0.9)$ & $39(4.8)$ & $33(4.1)$ & $32(4.0)$ & $90(11.1$ \\
\hline $\begin{array}{l}\text { Not worth } \\
\text { mentioning }\end{array}$ & $179(22.1)$ & $1(0.1)$ & $1(0.1)$ & $2(0.2)$ & $8(1.0)$ \\
\hline$N(\%)$ & & & & & \\
\hline$N$
\end{tabular}

\section{Challenges using behavioural pain tools}

Open-ended questions revealed that healthcare professionals reported a number of difficulties arising from the use of pain assessment tools amongst cognitively impaired older adults. Themes included the following: uncertainty about the observation; lack of information; lack of objectivity; lack of education, knowledge and expertise; lack of time; lack of interest and awareness; and lack of available pain tools. These are discussed below.

\section{Uncertainty about the observation}

Pain assessments may be inadequate when healthcare professionals are not 
confident about judging their observations. Participants across all countries were afraid of misinterpretation and cast doubt on the adequacy of their own pain assessments.

It's always difficult with certainty to know if the assessment is correct. Often the person does not have the ability to talk anymore, so we have to observe the body language and rely on the answer we get from pointing out the smiles.

\section{AQ13}

\section{Lack of information}

A lack of information was particularly problematic in acute care settings.

Sometimes it is difficult to interpret what is 'unusual' behaviour etc. (...) in the acute setting when staff doesn't know the client/patient in their normal condition.

Participants reported how it could be difficult to obtain information about the patient, required to make judgements about the presence of pain, when relatives or other informal carers were not present.

\section{AQ14}

\section{Lack of objectivity}

Many participants criticised observational pain assessment tools for being too difficult to complete due to the subjective nature of pain. A commonly reported problem was that staff perceived determining pain intensity as impossible and that pain assessments are therefore not reliable nor comparable.

High subjectivity in the evaluation of criteria, very different handling of the results of the assessment.

Participants reported feeling as though there is a lack of consistency between team members regarding a patient's pain status. 
Every employee has a different assessment or perceives nonverbal language in a different way.

Concerns about objectivity also appeared to stem from uncertainties surrounding the interpretation of pain assessments. Some participants reported that often results are interpreted differently by different members of the care team, resulting in different outcomes, especially amongst less knowledgeable staff. Some participants appeared afraid of misinterpretation in pain assessment.

\section{Lack of education, knowledge and expertise}

Inadequate education and expertise as to the conduct of pain assessments was reported as a common problem by participants. More specifically, the way pain assessments are implemented in their respective settings were described by participants to be insufficient, without any further education or training regarding how to use such assessments.

\section{Lack of time}

Participants frequently reported that insufficient time during shifts prevented comprehensive assessments of patient's pain. This was often presented as a "lack of resources to assess and manage this appropriately".

Little time is taken to actually observe the ill patient to a realistic assessment.

\section{Lack of interest and awareness}

The participants commonly stated that a lack of awareness of pain causes problems in pain assessment. In conjunction with this, some participants also felt that there was a general lack of interest regarding pain amongst staff in their work place.

Attention/awareness of nurses often too small to perceive pain immediately. 


\section{Lack of information}

A lack of information was described by participants to be problematic at several levels. First, patients are not able to communicate in a way healthcare professional expected and self-report is not given.

That the client can provide hardly where the pain is located. AQ15

Second, information is not sufficiently shared between healthcare staff and interdisciplinary cooperation lacks a relevant information base.

It is not enough reported.

AQ16

\section{Lack of available pain assessment tools}

A particular problem, raised by participants from across all participating countries, was that pain assessment tools are unknown, unavailable or insufficiently implemented in the workplace.

No tool is introduced in our home care centre. It is not implemented.

\section{Opportunities in using pain assessment}

Participants were asked to describe what they perceived was currently done well by institutions, in relation to pain assessment for older adults with cognitive impairment. Few participants answered this question, however of those who did, awareness, knowledge and experience and regulations were the three emerging themes. Each will be discussed below.

\section{Awareness}

It was reported that when healthcare professionals are aware of the importance 
of the observation pain assessment, pain assessments are more successful.

Since a week of awareness raising patients are more likely to have a pain assessment.

AQ18

Participants reported how they perceived that awareness raising events within their respective institutions had been successful.

We have found out the importance of have a focus on this as well as many other things.

\section{AQ19}

The implementation of a suitable tool e.g. an observational pain scale was often mentioned as being helpful.

\section{Knowledge and experience}

The participants described pain assessments as becoming easier when observational skills and individual experience increases. Otherwise pain assessment skills remained poor increasing the potential for inadequate use of pain assessments.

Experience has built up my assessment skills and confidence allows me to acknowledge limitations and where other professional input is needed.

\section{Regulations}

A policy framework was mentioned as being necessary to support pain assessment. In addition to this framework, participants reported how the knowledge and interdisciplinary cooperation of healthcare staff increases when staff is guided by regulations.

Good framework (standards, tools, support for nurse please use: nursing .... expert, regular training for newly recruited 
employees) (...) Assessment will be addressed and discussed inter-professional, very good cooperation (...).

$\mathrm{AQ} 21$

AQ22

\section{Differences across different work settings}

Table 3 provides information about participant's perceptions towards the utility of observation pain assessment tools. Few differences were demonstrated between healthcare settings. However participants employed within primary care reported the most difficulties with behavioural pain assessment tools. Primary care participants also preferred more time (more than $10 \mathrm{~min}$ ) to complete the assessments in comparison to the participants from other ( NH please replace ILTC, HC) settings.

\section{Differences across European countries}

Table 5 shows variations between participating countries in relation to the use of pain standards and assessment tools. The responses to the standards and guidelines or observational scales used are very heterogeneous and do not permit any differentiated remarks.

\section{Table 5}

A comparison of each responding country's use of pain standards and assessment tools AQ25

\begin{tabular}{|c|c|c|c|c|c|c|c|}
\hline & UK & NL & DE & DK & BE & SUI & AT \\
\hline $\begin{array}{l}\text { Use of (inter)national } \\
\text { or local standards }\end{array}$ & $n=28$ & $\begin{array}{l}n= \\
121\end{array}$ & $\begin{array}{l}n= \\
121\end{array}$ & $n=9$ & $n=35$ & $n=15$ & $n=38$ \\
\hline Yes & $\begin{array}{l}9 \\
(28.5)\end{array}$ & $\begin{array}{l}26 \\
(21.5)\end{array}$ & $\begin{array}{l}51 \\
(42.1)\end{array}$ & $\begin{array}{l}2 \\
(22.2)\end{array}$ & $\begin{array}{l}16 \\
(48.5)\end{array}$ & $\begin{array}{l}8 \\
(53.4)\end{array}$ & $\begin{array}{l}4 \\
(10.5)\end{array}$ \\
\hline No & $\begin{array}{l}14 \\
(50.0)\end{array}$ & $\begin{array}{l}69 \\
(57.0)\end{array}$ & $\begin{array}{l}61 \\
(50.4)\end{array}$ & $\begin{array}{l}5 \\
(55.6)\end{array}$ & $\begin{array}{l}13 \\
(39.4)\end{array}$ & $\begin{array}{l}5 \\
(33.3)\end{array}$ & 28 \\
\hline Don't know & $\begin{array}{l}5 \\
(21.5)\end{array}$ & $\begin{array}{l}26 \\
(21.5)\end{array}$ & $\begin{array}{l}9 \\
(7.4)\end{array}$ & $\begin{array}{l}2 \\
(22.2)\end{array}$ & $\begin{array}{l}4 \\
(12.1)\end{array}$ & $\begin{array}{l}2 \\
(13.3)\end{array}$ & $(73.7)$ \\
\hline Use observational & & $n=$ & $n=$ & & & & \\
\hline
\end{tabular}




\begin{tabular}{|c|c|c|c|c|c|c|c|}
\hline $\begin{array}{l}\text { tools in current } \\
\text { practise }\end{array}$ & $n=28$ & 137 & 147 & $n=9$ & $n=35$ & $n=17$ & $n=38$ \\
\hline Yes & $\begin{array}{l}13 \\
(46.4)\end{array}$ & $\begin{array}{l}47 \\
(34.3)\end{array}$ & $\begin{array}{l}66 \\
(44.9)\end{array}$ & $\begin{array}{l}5 \\
(55.6)\end{array}$ & $\begin{array}{l}17 \\
(48.6)\end{array}$ & $\begin{array}{l}9 \\
(52.9)\end{array}$ & $\begin{array}{l}5 \\
(13.2)\end{array}$ \\
\hline No & $\begin{array}{l}11 \\
(39.3)\end{array}$ & $\begin{array}{l}85 \\
(62.0)\end{array}$ & $\begin{array}{l}75 \\
(51.0)\end{array}$ & $\begin{array}{l}4 \\
(44.4)\end{array}$ & $\begin{array}{l}17 \\
(48.6)\end{array}$ & $\begin{array}{l}6 \\
(35.3)\end{array}$ & $\begin{array}{l}31 \\
(81.6)\end{array}$ \\
\hline Don't know & $\begin{array}{l}4 \\
(14.3)\end{array}$ & $\begin{array}{l}5 \\
(3.6)\end{array}$ & $\begin{array}{l}6 \\
(4.1)\end{array}$ & $0(0)$ & $\begin{array}{l}1 \\
(2.9)\end{array}$ & $\begin{array}{l}2 \\
(11.8)\end{array}$ & $\begin{array}{l}2 \\
(5.3)\end{array}$ \\
\hline
\end{tabular}

\section{Discussion}

\section{AQ26}

This survey of healthcare professionals from across the EU has provided important information surrounding current pain assessment practices of older adults with co-morbid dementia. Most notably, our findings reveal that less than half of healthcare staff work to any standard or use specific pain assessment tools in daily practice and many healthcare workers do not feel that they are knowledgeable enough in pain assessment and management to carry out this task effectively and achieve optimum pain care for this group of patients. AQ27

Our finding that the majority of participants did not utilise standards or pain assessment tools in practice was surprising. A limitation of our study is that there was a slight bias towards the survey circulating amongst those with an interest in pain, and so it would be expected that they would be most aware of such standards and guidelines. Therefore it seems plausible to consider that our findings may underestimate the scale of these difficulties. There was also a suggestion of a relationship between the use of standards and the use of observational tools in current practice; in countries where the majority of participants reported that (inter)national or local standards were being used, the use of pain assessment tools was more likely. While perhaps unsurprising, this finding supports the continued efforts to implement guidelines in clinical practice. 
In relation to pain assessment tools, a range of tools were reported to be in use, with differences in use between countries surveyed. Although overall, participants generally reported pain assessment tools to be easy/very easy to use ( $n=106,52 \%)$, it was in the interpretation of the results of such tools that caused confusion. Principally, participants had concerns surrounding the misinterpretation of recordings and uncertainty about the reliability and validity of the information collected. Participants often reported a preference for numeric or easy tick scales as opposed to selecting categories or open ended questions. This was particularly evident amongst participants from the UK who demonstrated a preference for the Abbey scale, which is a simple, easy to apply scale (Abbey; [1]). Similar findings were demonstrated for the Dutch sample mentioning the PACSLAC (-D; $[17,36])$ as one of the preferably used tools.

An important finding is that assessment is generally performed whilst providing nursing care $(84 \%, n=291)$. This was something highlighted in $70-80 \%$ of all participating countries and is an important factor to consider when developing or using behavioural pain assessment tools. Often these tools rely on facial expression of pain, which is not something that can be easily observed when providing care such as the washing or moving of the patient. In support of this, participants reported that facial expressions were the least useful indicator in comparison to all other items (e.g., vocalisation, body movement).

Healthcare professionals lack of pain management knowledge, and expertise, particularly in relation to older adults both with and without dementia, has been well documented. A survey exploring pain prevalence, use of interventions, assessment and management strategies and education and training distributed to 121 nursing homes found that only $44 \%$ of nursing homes provided education or training sessions to qualified staff on pain management, and $34 \%$ provided training for care assistants [3]. This finding has continued to be reported by more recent studies $[5,31]$ supporting the need for pain management strategies to be underpinned by training and education.

However in addition to education, aspects such as the attitudes of healthcare staff and managers have also been found to influence pain management practices in the care of older adults [5]. In line with our own findings, Barry et al. [5] found that around $60 \%$ of nursing home staff reported use of pain 
treatment guidelines but that almost two thirds of staff had not received any recent training on assessing or managing pain amongst patients with dementia. They also found that those who had received recent training were more confident with managing pain in this population group and were less likely to have concerns over opioid use with their residents with dementia. The findings of the current survey support previous findings and indicate that training needs, especially in long-term care settings, are still not being met. This study is not without its limitations that should be considered. This was a snap shot survey across Europe, and although some of the response rates from individual countries were quite low but the overall response level was relatively good. However, response rates per questionnaire item varied enormously. Respondents were not obliged to complete the questionnaire and therefore participants often did not respond to all questions, impacting upon response rates for individual items of the questionnaire. Since the questionnaire was primarily distributed through pain societies and pain subgroups of health professional organisations it is assumed that many of the respondents were somehow specialised in pain (e.g., specialised pain nurses). This may have caused selection bias and could have influenced our findings. This said, this would indicate that our results may underestimate the size of many of the problems reported by participants. In addition, we were underrepresented by participants from primary care settings. As the literature highlights the high incidence of pain amongst the older population living in the community [18] this is something to be addressed in future studies.

\section{Conclusion}

In spite of the limitations, there are some key findings emerging, which are consistent across all participating countries. Therefore, we can make the following recommendations:

- Pain education is required across all countries to include the implementation of guidelines and standards for assessment and subsequent management of pain.

- When designing pain standards and assessment tools for older adults with dementia we must consider the differences between settings and types of pain being assessed (e.g., primary vs. secondary care; chronic vs. acute 
pain).

- Improving the clinical usefulness of pain assessment tools is essential, especially in relation to interpreting their results and increasing user's confidence in their validity and reliability.

- This survey should be repeated across countries with specific strategies to enhance participation from our colleagues in primary care settings.

Author contribution All authors contributed to design the study. All authors discussed the results and commented on the manuscript.

Compliance with ethical guidelines

Conflict of interest S. Zwakhalen, R.E. Docking, I. Gnass, E. Sirsch, C. Stewart, N. Allcock and P. Schofield declare that they have no competing interests.

$\mathrm{AQ} 28$

This article does not contain any studies with human participants or animals performed by any of the authors.

AQ29

\section{References}

1. Abbey J, Piller N, De Bellis A et al (2004) The Abbey pain scale: a 1minute numerical indicator for people with end-stage dementia. Int J Palliat Nurs 10:6-13

2. Abdulla A, Adams N, Bone M et al (2013) Guidance on the management of pain in older people. Age Ageing 42(Suppl 1):i1-i57

3. Allcock N, Mcgarry J, Elkan R (2002) Management of pain in older people within the nursing home: a preliminary study. Health Soc Care Community 10:464-471

4. Alzheimer Europe (2009) Numbers of people with dementia in Europe 
higher than previously reported. http://www.alzheimereurope.org/News/Alzheimer-Europe/Monday-13-July-2009-Numbers-ofpeople-with-dementia-in-Europe-higher-than-previouslyreported/(language)/eng-GB. Accessed 19 June 2017

5. Barry HE, Parsons C, Passmore PA et al (2012) An exploration of nursing home managers' knowledge of and attitudes towards the management of pain in residents with dementia. Int J Geriatr Psychiatry 27:1258-1266

6. Basler HD, Huger D, Kunz R et al (2006) Beurteilung von Schmerz bei Demenz (BESD). Untersuchung zur Validitat eines Verfahrens zur Beobachtung des Schmerzverhaltens. Schmerz 20:519-526

7. Bieri D, Reeve RA, Champion GD et al (1990) The Faces Pain Scale for the self-assessment of the severity of pain experienced by children: development, initial validation, and preliminary investigation for ratio scale properties. Pain 41:139-150

8. Bruckenthal P, Reid MC, Reisner L (2009) Special issues in the management of chronic pain in older adults. Pain Med 10(Suppl 2):S67-S78

9. Brunier G, Carson MG, Harrison DE (1995) What do nurses know and believe about patients with pain? Results of a hospital survey. J Pain Symptom Manage 10:436-445

10. Buffum MD, Hutt E, Chang VT et al (2007) Cognitive impairment and pain management: review of issues and challenges. J Rehabil Res Dev $44: 315$

11. Coker E, Papaioannou A, Kaasalainen S et al (2010) Nurses' perceived barriers to optimal pain management in older adults on acute medical units. Appl Nurs Res 23:139-146

12. Conway Morris A, Howie N (2009) Pain in medical inpatients: an under-recognised problem? J R Coll Physicians Edinb 39:292-295

13. Cunningham C (2006) Managing pain in patients with dementia in 
hospital. Nurs Stand 20:54-58

14. Dionne CE, Dunn KM, Croft PR (2006) Does back pain prevalence really decrease with increasing age? A systematic review. Age Ageing $35: 229-234$

15. Docking RE, Fleming J, Brayne $\mathrm{C}$ et al (2014) Pain reporting in older adults: the influence of cognitive impairment-results from the Cambridge City $>75$ Cohort study. Br J Pain 8:119-124

16. Ferri CP, Prince M, Brayne C et al (2005) Global prevalence of dementia: a Delphi consensus study. Lancet 366:2112-2117

17. Fuchs-Lacelle S, Hadjistavropoulos T (2004) Development and preliminary validation of the pain assessment checklist for seniors with limited ability to communicate (PACSLAC). Pain Manag Nurs 5:37-49

18. Helme RD, Gibson SJ (2001) The epidemiology of pain in elderly people. Clin Geriatr Med 17:417-431

19. Herr K, Bjoro K, Decker S (2006) Tools for assessment of pain in nonverbal older adults with dementia: a state-of-the-science review. J Pain Symptom Manage 31:170-192

20. Mayring P (2010) Qualitative Inhaltsanalyse, Grundlagen und Techniken. Beltz, Weinheim, Basel

21. Mcauliffe L, Nay R, O'donnell M et al (2009) Pain assessment in older people with dementia: literature review. J Adv Nurs 65:2-10

22. Moschinski K, Kuske S, Andrich S et al (2017) Drug-based pain management for people with dementia after hip or pelvic fractures: a systematic review. BMC Geriatr 17:54

23. Niruban A, Biswas S, Willicombe SC et al (2010) An audit on assessment and management of pain at the time of acute hospital admission in older people. Int J Clin Pract 64:1453-1457 
24. Polomano RC, Dunwoody CJ, Krenzischek DA et al (2008) Perspective on pain management in the 21 st century. J Perianesth Nurs 23:S4-S14

25. Royal College of Physicians, British Pain Society (2007) The assessment of pain in older people: national guidelines

26. Scherder EJ (2000) Low use of analgesics in Alzheimer's disease: possible mechanisms. Psychiatry 63:1-12

27. Schofield P, O'mahony S, Collett B et al (2008) Guidance for the assessment of pain in older adults: a literature review. Br J Nurs 17:914-918

28. Schuurmans MJ, Shortridge-Baggett LM, Duursma SA (2003) The Delirium Observation Screening Scale: a screening instrument for delirium. Res Theory Nurs Pract 17:31-50

29. Shega JW, Weiner DK, Paice JA et al (2010) The association between noncancer pain, cognitive impairment, and functional disability: an analysis of the Canadian study of health and aging. J Gerontol A Biol Sci Med Sci 65:880-886

30. Takai Y, Yamamoto-Mitani N, Okamoto Y et al (2010) Literature review of pain prevalence among older residents of nursing homes. Pain Manag Nurs 11:209-223

31. Tarzian AJ, Hoffmann DE (2005) Barriers to managing pain in the nursing home: findings from a statewide survey. J Am Med Dir Assoc 6:S13-19

32. Thomas E, Mottram S, Peat G et al (2007) The effect of age on the onset of pain interference in a general population of older adults: prospective findings from the North Staffordshire Osteoarthritis Project (NorStOP). Pain $129: 21-27$

33. Weiner DK, Rudy TE, Morrow L et al (2006) The relationship between pain, neuropsychological performance, and physical function in communitydwelling older adults with chronic low back pain. Pain Med 7:60-70 
34. Word Health Organisation (WHO) (2012) Dementia: a public health priority.

http://www.who.int/mental_health/publications/dementia_report_2012/en/. Accessed 29 June 2017

35. Zwakhalen SM, Hamers JP, Abu-Saad HH et al (2006) Pain in elderly people with severe dementia: a systematic review of behavioural pain assessment tools. BMC Geriatr 6:3

36. Zwakhalen SM, Hamers JP, Berger MP (2007) Improving the clinical usefulness of a behavioural pain scale for older people with dementia. J Adv Nurs 58:493-502

37. Zwakhalen SM, Koopmans RT, Geels PJ et al (2009) The prevalence of pain in nursing home residents with dementia measured using an observational pain scale. Eur J Pain 13:89-93 